\title{
DISSENTING OPINION DAN \\ CONCURRING OPINION DALAM PUTUSAN MAHKAMAH KONSTITUSI
}

\author{
Haidar Adam Universitas A irlangga \\ mazhaidar@yahoo.co.id $\begin{aligned} & \text { Jl. A irlangga No. } 4 \text { - 6, Airlangga, } \\ & \text { Gubeng, Surabaya }\end{aligned}$
}

Abstract: This article discusses about dissenting opinion and concurring opinion in the decision of the Constitutional Court. Law enforcement can be done through the Constitutional Court in the form of law judicial review. The issue of dissenting opinion is regulated thro ugh Law N 0. 24 Year 2003 and Constitutional Court Regulation No. 6 of PMK Year 2005 concerning Procedural Law of T ests of Act. The phrase used in the Constitutional Court Law is "the different opinion of the judiciary members". The different opinion, according to Jimly, is divided into two namely dissenting opinion and concurrent opinion. A verdict is considered concurring if there is an argument by a member of the $p$ anel of judges that is different from that of the other members of the jud iciary but it does not affect the difference of the decision. $O \mathrm{n}$ the other hand, a decision is said to be dissenting if the opinion of a member of the panel of judges is different from that of the majority of the other members of the panel of judges and the difference is not merely in the case of reasoning but to to uching on the verdict.

Keywords: Dissenting opinion, concurring opinion, the court constitution's decision.

Abstrak: Penegakan hukum dapat dilakukan melalui pengadilan oleh Mahkamah Konstitusi dalam bentuk pengujian terhadap undang-undang. Masalah dissenting opinion diatur melalui Undang-Undang Nomor 24 Tahun 2003 dan Peraturan Mahkamah Konstitusi Nomor 6 PMK Tahun 2005 tentang Hukum A cara Pengujian Undang Undang. Frase yang dipakai dalam UUMK adalah "pendapat anggota majelis hakim yang berbeda". Pendapat yang berbeda menurut Jimly, dibedakan menjadi dua yaitu dissenting opinion dan concurrent opinion. Suatu putusan dianggap sebagai concurring apabila terdapat argumentasi anggota majelis hakim yang berbeda dengan mayo ritas anggota majelis hakim yang lain, namun tidak berimbas pada perbedaan amar putusan. Di sisi lain, suatu putusan dikatakan dissenting, jika pendapat suatu anggota majelis hakim berbeda dengan pendapat mayo ritas anggota majelis hakim yang lain dan sampai menyentuh pada amar putusan.

Kata Kunci: Dissenting opinion, concurring opinion, putusan Mahkamah Konstitusi. 


\section{Pendahuluan}

Bagi sebagian orang, hukum diidealkan sebagai perangkat untuk menggapai keadilan. $\mathrm{H}$ al ini menjadikan adanya tuntutan bahwa hukum mengandung substansi keadilan itu sendiri. Meski demikian, pada faktanya, banyak juga pihak yang berpendapat bahwa hukum dan lembaga hukum sebagai biang dari segala keruwetan sosial. Hukum senantiasa digunakan sebagai alat oleh penguasa untuk memberikan legitimasi bagi penguasa untuk memelihara kekuasaannya. Hukum adalah narasi besar dari penguasa untuk merepresi suara-suara lain yang dianggap melakukan reduksi atas kekuasaan yang dimilikinya. Penegakan hukum juga dilaksanakan secara tebang pilih. Kasus Setya Novanto telah memperlihatkan betapa hukum juga digunakan untuk menghindari penegakan hukum.

Penegakan hukum sebenarnya memiliki makna yang luas yang mencakup pula penegakan keadilan, tak sekedar penegakan undangundang. ${ }^{1}$ Dengan demikian, penegakan hukum meliputi proses pembuatan undang-undang yang memuat substansi yang berkeadilan serta pelaksanaan dari undang-undang tersebut secara berkeadilan pula. Salah satu institusi penegak hukum dalam arti yang luas ini adalah $M$ ahkamah Konstitusi (M K). U ntuk itu, M K, juga berkewajiban untuk menghadirkan keadilan tersebut dalam putusan-putusannya. M K merupakan salah satu pelaksana kekuasaan kehakiman yang ada di Indonesia. Banyak sebutan yang disematkan kepada Mahkamah Konstitusi (M K) seperti the sole interpreter of the constitution atau the guardian of the constitution. Sebutan tersebut mengandaikan tanggungjawab besar yang diemban oleh M K sekaligus menyiratkan ekspektasi yang besar dari masyarakat akan keadilan.

Dalam perjalanannya, MK mengalami pasang surut apresiasi dari masyarakat dalam bentuk puji dan caci. M isalnya, M K dipuji pada saat memberikan putusan terkait dengan dibatalkannya ketentuan calon Kepala $\mathrm{D}$ aerah yang harus berasal dari partai politik. ${ }^{2}$ D engan demikian, terbuka ruang bagi calon independen untuk turut berkontestasi dalam pemilihan kepala daerah. Beberapa minggu yang lalu, MK juga memberikan tafsiran yang ekstensif terhadap kata agama dalam U ndang

\footnotetext{
${ }^{1}$ Jimly Asshidd iq ie, M enuju N egara Hukum yang Demokratis, (Sekjend M KRI, 2008), 118.

${ }^{2}$ Haidar Adam, Putusan "Ultra Petita" Mahkamah Konstitusi dalam Perkara Pengujian UndangUndang, (Skripsi: 2008), 4.
} 
Undang Administrasi Kependudukan yang memungkinkan kelompok penganut kepercayaan juga tercakup didalamnya. Putusan ini direspon secara berbeda dalam masyarakat, ada yang mendukung dan ada yang menolaknya.

$\mathrm{Hal}$ terbaru, MK dijadikan bulan-bulanan oleh banyak pihak karena putusannya dianggap mendukung hak kelompok lesbian, gay, bisexual, transgender, intersex, dan queer (LGBTIQ). Sifat kontroversi dari putusan MK ini sangat wajar terjadi karena beberapa (atau satu) hakim memiliki pendekatan yang berbeda dalam menganalisa suatu kasus. Pemahaman mereka akan teks atau bahasa undang-undang juga beragam tergantung metode interpretasi yang digunakan. D itambah lagi, putusan M K tidak selalu bersifat bulat (unanimous), melainkan membuka peluang bagi pendapat yang berbeda, baik dalam bentuk dissenting opinion maupun concurring opinion. Walhasil, putusan yang dibuat akan tetap pada "labirin" ke(tidak)adilan bagi semua orang. Kondisi ini dalam beberapa hal sangat relevan jika dikaitkan dengan gagasan dekonstruksi dari J acques $D$ errida. U ntuk itu, makalah ini akan membahas tafsir penulis terhadap pemikiran Derrida tentang hukum dan mencari relevansinya dengan model putusan yang ada pada MK terutama yang bersifat dissenting maupun concurring.

\section{D errida dan Pemikirannya tentang $\mathrm{H}$ ukum dan Keadilan}

Sebelum menjelaskan tentang gagasan sentral dari Derrida, akan dijelaskan dulu keterangan sekilas tentang riwayat hidupnya. $\mathrm{Hal}$ ini dikarenakan pemikiran yang dihasilkan oleh Derrida akan lebih dapat dipahami jika kita juga memahami kehidupannya. ${ }^{3}$

Jackie Derrida yang selanjutnya lebih dikenal sebagai Jacques Derrida dilahirkan di El-Biar, Aljazair pada 15 Juli tahun 1930 dari keluarga Yahudi. ${ }^{4}$ Jejak historis menunjukkan bahwa wilayah ini merupakan "wilayah bergolak" di mana selama ribuan tahun para penakluk datang silih berganti mulai dari Bangsa Funisia, Romawi, Arab, T urki hingga bangsa Perancis. ${ }^{5} \mathrm{~K}$ ondisi bangsa Yahudi di Aljazair sebelum kedatangan bangsa Perancis sangat tidak menguntungkan. M ereka sangat dibatasi oleh otoritas (muslim) yang ada, bahkan dibedakan cara

\footnotetext{
${ }^{3}$ David M ikics, W ho W as Jacques Derrida?: An Intellectual Bio graphy, (Yale University Press, 2009), 11.

${ }^{4}$ Ibid., 13.

${ }^{5}$ Ibid., 14.
} 
berpakaiannya. ${ }^{6}$ Setelah Perancis mengkoloni Aljazair, kondisi bangsa Yahudi berangsur membaik karena Perancis berkepentingan terhadap jejaring perekonomian yang dimiliki oleh Bangsa Yahudi. ${ }^{7}$ Pada tahun 1870, terdapat hukum yang memberikan penegasan status kewarganegaraan Perancis kepada bangsa Yahudi yang ada di Aljazair. ${ }^{8}$ D engan demikian, mereka terhitung sebagai warga Perancis. N amun, hal ini tidak menjadikan kondisi lebih baik, malah yang terjadi adalah sebagian orang melakukan persekusi terhadap mereka karena dianggap sebagai antek penjajah. ${ }^{9} \mathrm{H}$ al ini berlanjut dan makin parah ketika Aljazair merdeka pada tahun 1962. Statistik kependudukan menunjukkan bahwa dari 140 ribuan penduduk Yahudi yang ada di Aljazair pada tahun 1948, berkurang drastis menjadi 500 orang pada tahun $1974 .{ }^{10}$ Sebagian besar dari mereka pergi meninggalkan Aljazair dan mencari tempat yang lebih aman, termasuk keluarga Jacques D errida yang pindah ke Perancis. ${ }^{11}$ Perancis, juga bukanlah tempat yang ramah bagi Jackie, usaha super keras harus dilakukannya untuk melakukan adaptasi yang prosesnya sangat melelahkan. Jejak akademisnya mulai terlihat semenjak diterimanya ia pada sekolah yang termasyhur di Perancis yaitu Ecole $\mathrm{N}$ ormal Superiuere. Di sekolah ini, ia memiliki kesempatan untuk berjumpa dengan intelektual Perancis garda depan semacam M ichel Foucault dan Louis Althusser. Bisa dikatakan bahwa "watak oposan" yang dimiliki oleh D errida sangat dibentuk oleh atmosfer kehidupannya pada saat itu yaitu dilahirkan dalam wilayah yang bergolak, minoritas dari sisi jumlah, dan imigran.

Nama Derrida tidak dapat lepas dari teori dekonstruksi yang digagasnya. M enurut Barbara Johnson sebagaimana dikutip oleh $\mathrm{Al}$ Fayyadl, dekonstruksi adalah strategi untuk mengurai teks. ${ }^{12}$ Secara etimologi, istilah dekonstruksi ini lebih dekat dengan istilah analisis daripada istilah destruksi. ${ }^{13}$ O leh karena itu, strategi dekonstruksi lebih ditujukan untuk mengurai struktur dan medan pemaknaan daripada

\footnotetext{
${ }^{6} \mathrm{lbid} ., 15$.

${ }^{7}$ lbid., 16.

${ }^{8} \mathrm{lbid} ., 17$.

${ }^{9} \mathrm{lbid}$.

${ }^{10} \mathrm{lbid}$

${ }^{11} \mathrm{lbid}$.

${ }^{12}$ M uhammad AI FayyadI, Derrida, Cetakan ke-II, (Yogyakarta: LKIS, 2012), 79.

${ }^{13} \mathrm{Ibid}$. Band ingkan dengan Anthon F. Susanto, Dekonstruksi Hukum, (Yo gyakarta: Genta Publishing, 2010), 15.
} 
operasi yang merusak teks itu sendiri. ${ }^{14} \mathrm{~K}$ arenanya, ketika cara baca yang dekonstruktif ini diterapkan pada suatu teks, maka tujuan yang ingin diungkapkan adalah untuk menelisik oposisi-oposisi hirarkis yang ada di dalam teks sehingga klaim bahwa satu pemaknaan atas suatu teks adalah yang paling benar dibandingkan dengan pemaknaan yang lain, dapat dihindari. ${ }^{15}$ Untuk itu, keberadaan suatu teks akan selalu ditunda pemaknaannya. Penundaan ini membuka ruang dinamis bagi interpretasi dari sudut pandang lainnya.

Derrida oleh para pemikir taksonom, dimasukkan pada pemikir posmodernisme. Filsafat pada era posmodernisme ini lebih mengarah kepada bahasa (linguistic turn). ${ }^{16} \mathrm{D}$ emikian pula yang ditekuni $\mathrm{D}$ errida. Gagasan sentralnya tentang bahasa juga diturunkan dari analisanya tentang bahasa. Bahasa adalah sistem tanda di mana di dalamnya memuat unsur penanda (signifier) dan tinanda (signified). Penanda merupakan citra akustik yang muncul sedangkan tinanda merupakan abstraksi konsep yang ditunjuk oleh penanda. ${ }^{17}$ Sebagai sistem tanda, maka bahasa memiliki sifat yang arbitrer (manasuka). ${ }^{18}$ Semisal, kita tidak pernah tahu jika kenapa "kertas" itu dinamakan kertas dan bukan babi. Karena segala bentuk tatanan dan jejaring sosial yang terbentuk dikomunikasikan dengan bahasa, maka pada hakikatnya tidak ada pondasi yang kuat bagi suatu "kebenaran". Di titik inilah kritik D errida terhadap modernisme yang mendewakan logosentrisme yang dicirikan dengan adanya narasinarasi besar.

Tidak banyak tulisan Derrida yang menyangkut hukum secara langsung. Tulisannya tentang hukum dapat ditemukan dalam esainya yang berjudul Force of Law: the Mystical Foundation of Authority terjemahan dari Bahasa Perancis Force de loi: Le fondement mystique de I'autorité. ${ }^{19} \mathrm{M}$ enurut D errida, hukum tidaklah identik dengan keadilan. ${ }^{20}$ H ukum merupakan paksaan(kekerasan) karena di dalamnya mengandung makna terdapat otoritas yang dapat memaksakan penerapan hukum tersebut dan oleh karenanya inkonsisten dengan gagasan tentang keadilan

\footnotetext{
${ }^{14} \mathrm{lbid}$.

${ }^{15} \mathrm{lbid}$.

${ }^{16} \mathrm{Ibid} .29$.

${ }^{17} \mathrm{lbid}$.

${ }^{18}$ F. Budi Hardiman, M elampaui Positivisme dan M odernitas, (Jakarta: Kanisius, 2003), 183.

${ }^{19}$ Jacques Derrida, Force de loi: Le "fondement mystique de l'autorité", 11 CARDO ZO LAW REVIEW 919-1045, (1990).

${ }^{20} \mathrm{Ibid}$., 946.
} 
itu sendiri. D itambahkan oleh D errida bahwa keberlakuan hukum juga memiliki fondasi yang rapuh dikarenakan ia dibangun atas dasar hal yang diluar dari hukum itu sendiri. Keadilan, bagi D errida merupakan hal yang tak terhitung, dan oleh karenanya merupakan suatu ketidakmungkinan. Bagaimana "mendekati" keadilan?, D errida menawarkan dekonstruksi sebagai sarana untuk menuju keadilan. Bahkan Derrida menyatakan bahwa dekonstruksi adalah keadilan itu sendiri. ${ }^{21}$

\section{Pengertian D issenting 0 pinion}

Pada dasarnya, suatu putusan hakim dalam suat perkara tidak seluruhnya hakim yang memutus perkara secara utuh dan bulat menyetujui putusan yang telah dijatuhkan. Adakalanya seorang hakim dapat juga tidak menyetujui terhadap putusan yang telah diambil dalam majelis hakim tersebut. Jika terjadi hal demikian, pendapat hakim yang berbeda disebut sebagai dissenting opinion. ${ }^{22}$

Dissenting opinion adalah pendapat yang berbeda secara substansif sehingga menghasilkan amar yang berbeda, misalnya mayoritas hakim menolak permohonan, tetapi hakim minoritas mengabulkan permohonan yang bersangkutan dan sebaliknya. ${ }^{23}$

Concurring opinion adalah pendapat/putusan yang ditulis oleh seorang hakim atau lebih yang setuju dengan pendapat mayoritas majelis hakim yang suatu perkara, namun memiliki alasan yang berbeda. ${ }^{24}$

Dikaji dari perspektif perbandingan hukum, maka dissenting opinion merupakan terminologi dan substansi dari rumpun hukum Anglo Saxon, seperti Amerika dan Kerajaan Inggris dan merupakan salah satu bagian dari pendapat hukum (legal opinion). Sebagai komparasi, hakikatnya pendapat hukum (legal opinion) dapat terdiri dari atas:

a. Judicial opinion adalah sebagai pernyataan atau pendapat hakim dalam memutuskan perkara, baik terhadap perkara perdata maupun pidana.

b. M ajority opinion adalah pendapat hakim yang disetujui oleh mayoritas hakim pada pengadilan.

\footnotetext{
${ }^{21} \mathrm{lbid}$.

22 Lilik M ulyadi, Putusan Hakim dalam Hukum Acara Perdata Indonesia, (Bandung: PT Citra Aditya Bakti, 2009), 165.

${ }^{23}$ Imam M ahdi, Hukum Tata N egara Ind onesia, (Yogyakarta: Teras, 2011), 294.

24 Siti Aminah dan Uli Parulian Sihombing, Memahami Pendapat Berbeda (Dissenting 0 pinion) Putusan Uji M ateriil UU Penodaan A gama, (Jakarta: The Ind onesian Legal Resource Center, 2011), 30.
} 
c. D issenting opinion adalah pendapat hakim yang berbeda dalam suatu perkara yang dilakukan secara tertulis dalam putusan.

d. C oncurring opinion adalah pendapat tertulis dari beberapa hakim yang setuju terhadap kelompok mayoritas, tetapi tertulis dengan cara yang berbeda.

e. Plurality opinion adalah pendapat yang bersifat plural dari suatu kelompok lingkungan peradilan dan diterima oleh kelompok mayoritas di pengadilan.

f. M emorandum opinion adalah catatan dari lembaga peradilan tertinggi pada lembaga peradilan yang lebih rendah tingkatannya. ${ }^{25}$

Pada negara-negara penganut sistem Eropa kontinental, dissenting opinion sebenarnya tidak dikenal. Akan tetapi, seiring dengan perkembangan zaman, maka dissenting opinion telah dikenal dan ditetapkan dalam praktik peradilan yang telah dilakukan oleh $\mathrm{M}$ ahkamah Agung Republik Indonesia.

Di Indonesia, dissenting opinion pertama kali lahir tidak mempunyai landasan yuridis formal karena praktik hakim yang berkembang. Pertama kalinya dissenting opinion ini memiliki landasan yuridis di dalam UU Kepailitan N 0. 4 Tahun $1998 .{ }^{26}$ Pada awalnya, dissenting opinion ini diperkenalkan pada pengadilan niaga, namun kini telah diperbolehkan di pengadilan lain, termasuk dalam uji materiil undang-undang di M K. ${ }^{27}$

Pada tataran normatif, dissenting opinion diatur dalam pasal 30 ayat (2) Undang-U ndang Nomor 3 Tahun 2009 tentang M ahkamah Agung yang menetapkan bahwa dalam sidang permusyawaratan setiap hakim agung wajib menyampaikan pertimbangan atau pendapat tertulis terhadap perkara yang sedang diperiksa dan menjadi bagian yang tidak terpisahkan dari putusan. Kemudian, dalam ayat (3) disebutkan bahwa dalam hal sidang permusyawaratan tidak dapat dicapai mufakat bulat, pendapat hakim agung yang berbeda wajib dimuat dalam putusan. Selanjutnya, dalam pasal 19 ayat (4) Undang-undang N omor 4 Tahun 2004 tentang Kekuasaan Kehakiman yang menetapkan bahwa dalam sidang yang permusyawaratan, setiap hakim wajib menyampaikan

\footnotetext{
${ }^{25}$ Imam M ahdi, Hukum Tata N egara Indonesia,294.

${ }^{26}$ Sunarmi, "Dissenting 0 pinion sebagai W ujud Transparansi dalam Putusan Peradilan", Jurnal Equality, Vol. 12 No. 2 Agustus 2007, 147.

27 Siti Aminah dan Uli Parulian Sihombing, Memahami Pendapat Berbeda (Dissenting O pinion) Putusan Uji M ateriil UU Penodaan A gama, 32.
} 
pertimbangan atau pendapat tertulis terhadap perkara yang sedang diperiksa dan menjadi bagian yang tidak terpisahkan dari putusan. Berikutnya, dalam ayat (5) disebutkan bahwa dalam hal sidang permusyawaratan tidak dapat dicapai mufakat bulat, pendapat hakim yang berbeda wajib dimuat dalam putusan. ${ }^{28}$

Pasal 45 ayat (7) menyebutkan "Dalam hal musyawarah sidang pleno setelah diusahakan dengan sungguh-sungguh tidak dapat dicapai mufakat bulat, putusan diambil dengan suara terbanyak", sedangkan ayat (8) menyebutkan "Dalam hal musyawarah sidang pleno hakim-hakim kontitusi sebagaimana dimaksud ayat (7) tidak dapat diambil dengan suara terbanyak, suara terakhir ketua sidang pleno konstitusi menentukan"29

$\mathrm{H}$ akim dalam memutus perkara seharusnya berpegang teguh pada ketentuan perundang-undangan yang berlaku untuk memenuhi rasa keadilan. ${ }^{30}$ Pemberlakuan dissenting opinion, sejalan dengan semangat keterbukaan. Kalau pembacaan putusan majelis hakim bersifat terbuka, sudah semestinya proses pembentukan putusan itu pun terbuka. Penerapan dissenting opinion bukan sekadar perlu sebagai sarana mengontrol hakim, tetapi juga untuk pengembangan pendidikan hukum. D engan mengetahui adanya perbedaan pendapat di antara hakim anggota majelis hakim, kalangan akademik bisa melakukan kajian. ${ }^{31}$

Penerapan dissenting opinion sejalan dengan semangat keterbukaan. Dengan pencantuman pendapat hakim tersebut hak masyarakat untuk mendapatkan informasi secara optimal diberikan. Akses masyarakat untuk mendapatkan putusan pengadilan sebaiknya juga ditingkatkan. M eskipun dissenting opinion diterapkan, tetapi jika masyarakat tetap kesulitan mendapatkan salinan putusan pengadilan seperti saat ini, kebijakan tersebut tak berarti. Karena masyarakat tetap saja kesulitan mengetahui pendapat hakim yang berbeda. ${ }^{32}$

Adanya dissenting opinion ini membuat masyarakat kini mempunyai harapan baru putusan pengadilan akan lebih berkualitas. Sebab, hakim tak bisa lagi menyembunyikan pikirannya dalam putusan.

\footnotetext{
${ }^{28}$ Lilik Mulyadi, Putusan Hakim dalam Hukum Acara Perdata Ind onesia, 166.

${ }^{29}$ Imam M ahdi, Hukum Tata N egara Indonesia, 293.

30 Indra Sukma Putra, Sri Wahyuningsih Yulianti, Bintoro Adi W icaksono, "Analisis Putusan Dissenting $O$ pinion berdasarkan Kitab Undang-Undang Hukumacara Pidana (KUHAP) Pada Perkara Penipuan (Studi Putusan M ahkamah Agung N omor: 2253 K/Pid/2012), Verstek, Vol 3, No 3,2015,5-6.

${ }^{31}$ Sunarmi, "Dissenting 0 pinion sebagai W ujud T ransparansi dalam Putusan Peradilan", 150. ${ }^{32} \mathrm{lbid}$.
} 
D engan menganalisis putusan itu, masyarakat dengan mudah akan dapat menemukan mana hakim yang sudah terkontaminasi dan yang masih murni dengan pendapat hukum yang mengedepankan rasa keadilan. Dissenting opinion akan mendorong hakim lain mempunyai pilihan dalam menentukan putusan dalam perkara yang sama. Ini akan mendorong lahirnya yurisprudensi yang lebih bersifat tetap. ${ }^{33}$

\section{M ahkamah Konstitusi}

Secara konstitusional, lahirnya Mahkamah Konstitusi pada saat perubahan ketiga Undang-Undang Dasar Republik Indonesia Tahun sidang MPR tanggal 9 November 2011. Sejak saat itulah gagasan pembentukan M K diadopsi dalam sistem ketatanegaraan Indonesia, sebagai salah satu kekuasaan kehakiman baru yang terpisah dengan $M$ ahkamah Agung.

Lahirnya M K merupakan jawaban atas keinginan agar lembaga yudisia dapat melakukan pengujian atas UU terhadap UUD yang sebelumnya sama sekali tidak dapat dilakukan. M emang sejak tahun 2000, ada TAP M PR N 0. III/M PR/2000 yang menyerahkan pengujian UU terhadap UUD kepada MPR. Namun, selain itu bukan merupakan pengujian oleh lembaga yudisial yang dapat menggambarkan checks and balance, sejalan dengan tata hukum baru yang tidak lagi mengenal TAP MPR sebagai bagian dari peraturan perundang-undangan, maka pembentukan M K merupakan pilihan yang rasional. ${ }^{34}$

$M$ ahkamah Konstitusi adalah sebuah lembaga negara yang ada setelah adanya amandemen UUD 1945. Dalam konteks kenegaraan, M ahkamah Konstitusi dikonstruksikan: Pertama, sebagai pengawal konsitusi yang berfungsi menegakkan keadilan konsitusional di tengah kehidupan masyarakat. Kedua, M ahkamah Konsitusi bertugas mendorong dan menjamin agar konsitusi dihormati dan dilaksanakan oleh semua komponen negara secara konsisten dan bertanggungjawab. Ketiga, di tengah kelemahan sistem konstitusi yang ada, Mahkamah Konstitusi berperan sebagai penafsir agar spirit konstitusi selalu hidup dan mewarnai keberlangsungan bernegara dan bermasyarakat. ${ }^{35}$

\footnotetext{
${ }^{33} \mathrm{lbid} ., 152$.

${ }^{34}$ Imam M ahdi, Hukum Tata N egara Ind onesia, 280.

${ }^{35}$ T itik T riwulan Tutik, Pokok-Pokok Hukum T ata N egara Ind onesia Pasca Amendemen UUD 1945, (Jakarta: Cerdas Pustaka, 2008), 260.
} 
M ahkamah Konstitusi RI mempunyai 4 (empat) kewenangan dan 1 (satu) kewajiban sebagaimana diatur dalam U ndang-Undang D asar 1945. M ahkamah Konstitusi berwenang mengadili pada tingkat pertama dan terakhir yang putusannya bersifat final untuk:

1. M enguji undang-undang terhadap Undang-U ndang D asar N egara Republik Indonesia T ahun 1945.

2. M emutus Sengketa kewenangan lembaga negara yang kewenangannya diberikan oleh UUD N egara Republik Indonesia Tahun 1945.

3. M emutus pembubaran partai politik, dan

4. M emutus perselisihan tentang hasil pemilihan umum.

5. M ahkamah Konstitusi wajib memberikan putusan atas pendapat DPR bahwa Presiden dan/atau Wakil Presiden diduga melakukan pelanggaran (impeachment).

Berdasarkan UU Nomor 8 Tahun 2011 Mahkamah Konstitusi memiliki kewenangan tambahan $M$ emutus perselisihan hasil pemilihan Gubernur, Bupati, dan Walikota selama belum terbentuk peradilan khusus. $^{36}$

Berdasarkan ketentuan tersebut, maka setiap putusan $M$ ahkamah Konstiusi bersifat final. Artinya dalam hal pelaksanaan kewenangan ini tidak ada mekanisme banding atau kasasi etrhadap putusan yang dibuat $M$ ahkamah Konstitusi untuk perkara-perkara yang berkenaan dengan kewenangan tersebut. ${ }^{37}$

D alam melaksanakan tugas sebagai lemabga yang diberi hak untuk menguji peraturan dan perundang-undangan, $\mathrm{MA}$ dan $\mathrm{MK}$ diberi kewenangan juga untuk mengatur tata cara pengujiannya. M A biasanya mengeluarkan Peraturan Mahkamah Agung (PEMA), sedangkan MK mengeluarkan Peraturan M ahkamah Konstitusi (PM K). D i dalam UUD 1945 diberikan batasan yang jelas bahwa MK berwenang menguji Undang-undang terhadap UUD, sedangkan MA menguji peraturan perundang-undangan di bawah undang-undang. Sedangkan pengujian terhadap lampiran UU, misalnya lampiran tentang UU APBN UU

\footnotetext{
${ }^{36}$ "Kedudukan dan Kewenangan", http://www. mahkamahkonstitusi.go.id/index.php? page =web.ProfilM K\&id=3.

${ }^{37}$ T itik T riwulan Tutik, Pokok-Pokok Hukum T ata Negara Ind onesia Pasca Amendemen UUD 1945, 263.
} 
Ratifikasi, mengingat lampiran tersebut secara materiil melekat pada UU, maka M K berwenang menguji lampiran tersebut. ${ }^{38}$

\section{Mahkamah Konstitusi dan Pengaturan Putusan yang Memuat Pendapat Berbeda}

David S. Law dan M ira Versteeg telah mengidentifikasi beberapa tren/kecenderungan yang terjadi dalam kaitannya dengan konstitusi yang ada di dunia. ${ }^{39}$ Kecenderungan pertama adalah fenomena hak-hak yang merayap (creeping rights). Tren ini menjelaskan bahwa dalam enam dekade terakhir (1950an-2010an) banyak sekali negara-negara yang menambahkan pengaturan tentang hak kedalam konstitusinya. ${ }^{40}$ Terminologi yang dipakai juga beragam meliputi hak asasi manusia (Indonesia memakai istilah ini), hak fundamental, hak warga negara, hak dasar, dll. Jika dilihat, kecenderungan ini tidak dapat dilepaskan dari gagasan konstitusionalisme global yang banyak sekali dipengaruhi perkembangan hak asasi manusia yang diawali oleh Deklarasi U niversal H ak Asasi M anusia (D U H AM ) pada tahun 1948.

Kecenderungan kedua adalah penyebaran ide pengujian norma oleh lembaga yudisial (judicial review). ${ }^{41}$ Judicial review ini memberi peluang bagi lembaga yudisial untuk menguji konsistensi norma yang telah dihasilkan oleh lembaga legislatif maupun eksekutif dengan norma yang lebih tinggi. Gagasan ini berkembang secara teoritik akibat dua pemikiran yaitu gagasan tentang hirarki hukum dari $\mathrm{H}$ ans $\mathrm{K}$ elsen dan juga adanya ide supremasi konstitusi. Penanda penting bagi menyebarnya ide tentang judicial review ini biasanya dikaitkan dengan kasus $\mathrm{M}$ arbury vs. M adison yang terjadi di Amerika Serikat. ${ }^{42}$

Kecenderungan ketiga dalam konstitusionalisme global adalah terdapatnya hak-hak yang bersifat "generic". Bersifat generic di sini maksudnya adalah bahwa hak-hak tersebut terdapat di sebagian besar konstitusi yang ada didunia. Salah satu contoh dari hak yang bersifat

\footnotetext{
${ }^{38}$ Imam M ahdi, Hukum Tata N egara Ind onesia, 282.

${ }^{39}$ Law, David S. and Versteeg, M ila, The Evolution and Id eology of Global Constitutionalism (June 13, 2011). California Law Review, Vol. 99, p. 1163, 2011; APSA 2010 Annual Meeting Paper; 5th Annual Conference on Empirical Legal Studies Paper; W ashington University in St. Louis Legal Studies Research Paper No. 10-10-01. Available at SSRN: https://ssrn.com/abstract=1643628, 1194.

${ }^{40} \mathrm{lbid}$.

${ }^{41} \mathrm{lbid}$.

${ }^{42}$ A hmad Syahrizal, Perad ilan Konstitusi, (Jakarta: Prad nya Paramitha, 2006), 8-9.
} 
generic ini adalah hak kebebasan untuk beragama dan berkeyakinan yang keberadaannya dapat ditemukan di $97 \%$ konstitusi yang ada di dunia. ${ }^{43}$ Jika dilihat beberapa kecenderungan di atas, sebenarnya terdapat keterkaitan yang sangat erat antara satu tren dengan tren lainnya. Pranata judicial review juga dapat ditemukan dalam konteks Indonesia. Institusi yang melakukan kewenangan tersebut berada pada dua lembaga kekuasaan kehakiman, yaitu Mahkamah Agung (MA) dan Mahkamah Konstitusi (M K). M A berwenang menguji peraturan perundangan dibawah undangundang sedangkan $\mathrm{MK}$ berwenang untuk menguji undang-undang terhadap U UD. D engan demikian, kelahiran M K tak bisa dipisahkan dari kepentingan untuk melakukan proteksi terhadap hak-hak yang terdapat dalam konstitusi.

Kewenangan untuk menguji ini merupakan kewenangan inti yang dimiliki oleh M K. Hal ini dikarenakan keberadaan MK tak lepas dari migrasi ide tentang pengujian konstitusional. Selain itu, secara faktual, dari beberapa kewenangan yang dimiliki oleh $\mathrm{M} \mathrm{K}$, kewenangan pengujian undang-undang merupakan yang paling intens dilakukan. Studi yang dilakukan Zendy dan $\mathrm{H}$ aidar memperlihatkan bahwa dalam kurun waktu antara tahun 2003 sampai dengan 2012, terdapat sekurang-kurangnya 447 perkara pengujian undang-undang. ${ }^{44} \mathrm{D}$ ari 447 putusan tersebut, 131 memuat pendapat yang berbeda. ${ }^{45} \mathrm{D}$ alam laporan Setara Institute, terdapat 5 putusan yang memuat dissenting opinion sepanjang 2016 sampai dengan $2017 .{ }^{46}$ Jika dibandingkan dengan periode sebelumnya, jumlah hakim dissenter semakin menyusut.

Jelas, jumlah ini melampaui jumlah perkara lain yang menjadi kewenangan MK. Untuk itu, wajar jika terdapat anggapan bahwa pengujian undang-undang merupakan core business dari $\mathrm{M} \mathrm{K}$.

Pengaturan tentang dissenting opinion dalam UUD NRI 1945 tidaklah disebut secara eksplisit. Dalam Bab mengenai Kekuasaan Kehakiman, tidak ada pasal yang menyebutkan perihal pendapat yang berbeda ini. Ketentuan dalam pasal 24 ayat (1) hanya menyebutkan tentang kekuasaan kehakiman yang merupakan kekuasaan yang merdeka untuk menyelenggarakan peradilan guna menegakkan hukum dan

\footnotetext{
${ }^{43}$ Law, David S. and Versteeg, Mila, 1162-1163.

${ }^{44}$ Zendy W ulan Ayu \& Haidar Adam, "Putusan Dissenting 0 pinion Mahkamah Konstitusi Dalam Perkara Pengujian Undang-Undang", Yuridika: Volume 29 No 2, M ei-A gustus 2014, 167.

${ }^{45} \mathrm{lbid}$.

${ }^{46}$ Setara Institute, Kinerja M ahkamah Konstitusi RI 2016-2017, A gustus 2017, 21.
} 
keadilan. Lebih Ianjut, dalam ayat duanya disebutkan bahwa kekuasaan kehakiman dilaksanakan oleh dua institusi yaitu M ahkamah Agung dan M ahkamah Konstitusi. Mekanisme dalam pengambilan keputusan, termasuk didalamnya yang memuat pendapat yang berbeda merupakan bagian dari hukum acara. Dalam khazanah ilmu hukum, hukum acara (hukum formil) adalah hukum yang berisi prosedur yang ditujukan untuk mempertahankan hukum materiil. ${ }^{47}$ D alam U UD N RI 1945, pengaturan hukum acara terkait dengan hukum acara pada masing-masing pelaku kekuasaan kehakiman diatur lebih lanjut dengan undang-undang. ${ }^{48}$ Ketentuan pasal 24 C ayat (6)UUD NRI 1945 menyebutkan "pengangkatan dan pemberhentian hakim konstitusi, hukum acara serta ketentuan lainnya diatur dengan undang-undang". D engan rumusan norma yang demikian, maka terdapat amanah dari UUD untuk mengatur perihal ketentuan terkait dengan $\mathrm{MK}$ dalam suatu undang undang tersendiri. ${ }^{49}$

Sebagai tindak lanjut dari amanah yang telah diberikan Konstitusi, maka dibuatlah undang undang yang mengatur keberadaan $\mathrm{M} \mathrm{K}$ yaitu $\mathrm{UU}$ N omor 24 tahun 2003 tentang M ahkamah Konstitusi (U U M K). D alam U UMK, diatur perihal kedudukan, hakim konstitusi, kewenangan M K, juga hukum acara yang berlaku pada M K. H ukum acara M K diatur dalam bab $\mathrm{V}$ mulai dari pasal 28 sampai dengan pasal 85 termasuk di dalamnya adalah hukum acara pengujian undang undang. Terkhusus masalah putusan, diatur pada bagian ketujuh dalam bab ini. Pengambilan putusan, sebagaimana diatur dalam hukum acara, dimulai dengan melakukan deliberasi atas perkara yang dimohonkan. Proses deliberasi itu dimulai dengan masing-masing hakim mengemukakan pendapatnya atas suatu perkara dalam sidang permusyawaratan (rapat permusyawaratan hakim). ${ }^{50}$

\footnotetext{
47 Tim Penyusun Hukum Acara Mahkamah Konstitusi, Hukum Acara Mahkamah Konstitusi, Sekretariat Jend eral Mahkamah Konstitusi, 14.

${ }^{48}$ Pasal 24 B ayat (5) mengatur amanat pengaturan hukum acara untuk Mahkamah Agung dan lingkungan peradilan yang ada dibawahnya. Sedangkan untuk hukum acara Mahkamah Konstitusi diatur dalam pasal $24 \mathrm{C}$ ayat (6).

${ }^{49}$ Dalam teknik penulisan perundangan, kata "dengan" dibedakan dengan kata "dalam". Frase "diatur dengan undang-undang" bermakna pengaturan tersebut mestilah diatur dalam suatu Undang-undang secara tersendiri (khusus). Sedangkan frase "diatur dalam undang undang" memiliki makna pengaturan tersebut diatur dalam Undang-undang tanpa harus dibuat dalam suatu Undangundang yang khusus, misalnya pengaturan tentang DPD, bisa d iatur d alam Undang Undang tentang Pemilihan Umum maupun undang-undang tentang susunan dan kedudukan anggota DPR, DPD, DPRD ...

${ }^{50}$ Pasal 45 ayat (5) UUM K
} 
T ak sekedar pendapat secara lisan, melainkan pendapat atau pertimbangan dari hakim-hakim tersebut mestilah disampaikan secara tertulis. ${ }^{51}$ Tahapan selanjutnya adalah mencari kemufakatan bulat dalam musyawarah. ${ }^{52}$ Akan tetapi, jika mufakat bulat tersebut tidak tercapai meskipun telah diusahakan secara sungguh-sungguh, maka pengambilan putusan akan dilakukan dengan suara terbanyak. ${ }^{53} \mathrm{D}$ ijelaskan juga dalam U U M K tersebut, bahwa peran ketua sidang sangat signifikan dalam hal terjadi suara yang berimbang dalam pengambilan keputusan. Dalam konteks ini, Ketua menjadi decision maker apakah suatu perkara pengujian undang undang ditolak atau dikabulkan atau dikabulkan sebagian atau bahkan tidak dapat diterima (niet ontvantkelijk verklaard). ${ }^{54}$ Pada akhirnya, jika tetap terjadi perbedaan pendapat diantara para hakim, maka hakim yang memiliki pendapat yang berbeda dapat memuat pendapatnya (yang berbeda) pada putusan. M enurut Jimly, penuangan pendapat yang berbeda dalam putusan ini merupakan hal yang harus dilakukan jika pemahaman atas ketentuan tersebut dimaknai secara "plain". ${ }^{55} \mathrm{~N}$ amun dalam praktiknya, hal tersebut susah untuk direalisasikan.

Secara eksplisit, tidak ada pengaturan tentang dissenting opinion. Frase yang dipakai dalam U U M K adalah "pendapat anggota majelis hakim yang berbeda". Pendapat yang berbeda menurut J imly, dibedakan menjadi dua yaitu dissenting opinion dan concurrent opinion atau consenting opinion. ${ }^{56}$ Suatu putusan dianggap sebagai concurring apabila terdapat argumentasi anggota majelis hakim yang berbeda dengan mayoritas anggota majelis hakim yang lain namun tidak berimbas pada perbedaan

\footnotetext{
${ }^{51} \mathrm{lbid}$.

${ }^{52}$ Pasal 45 ayat (4), (6).

${ }^{53}$ Pasal 45 ayat (7).

${ }^{54}$ Pasal 45 ayat (8).

${ }^{55}$ Jimly Asshiddiqie, Hukum Acara Pengujian Undang-Undang, (Jakarta: Sinar Grafika, 2012), 201. Dalam khasanah teknik penulisan perund ang-undangan, dikenal apa yang d isebut seb agai op erator norma yang berisi kata yang mengand ung perintah, izin, larangan yang biasanya direpresentasikan kata "wajib" , "harus", "dilarang", "dapat". Dalam rumusan pasal 45 ayat(10) operator normanya kurang jelas karena tidaklah tampak secara eksplisit. Dalam pasal tersebut dipakai frase "dimuat dalam putusan" tidak ada kata-kata "harus" atau "wajib". Bandingkan dengan ketentuan dalam UUKK yang mengatur pend ap at berbeda di lingkungan Mahkamah A gung, dalam pasal 19 ayat (5) di sana frase yang digunakan adalah "wajib dimuat".

${ }^{56} \mathrm{lbid}$., 200. Jimly menggunakan istilah concurrent opinion untuk mendeskrip sikan putusan yang memuat persetujuan seorang atau beberapa anggota majelis hakim dengan pendapat mayoritas anggota majelis hakim yang lain, namun memiliki penalaran hukum (argumentasi) yang berbeda. Seb enarnya, istilah yang lazim digunakan adalah concurring opinion.
} 
amar putusan. ${ }^{57}$ Di sisi lain, suatu putusan dikatakan dissenting jika pendapat suatu anggota majelis hakim berbeda dengan pendapat mayoritas anggota majelis hakim yang lain dan perbedaan tersebut tak sekedar dalam hal penalaran saja, melainkan sampai menyentuh pada amar putusan..$^{58}$

Selain UUMK terdapat undang-undang lain yang mengatur tentang kekuasaan kehakiman yaitu U ndang U ndang Nomor 4 tahun 2004 tentang Kekuasaan Kehakiman (UUKK). UUKK memuat ketentuan tentang pendapat yang berbeda ini dalam pasal 19 ayat (5). $\mathrm{N}$ amun, ketentuan tentang pendapat yang berbeda dalam pasal tersebut dimaksudkan untuk hukum acara yang ada dalam lingkup $M$ ahkamah Agung.

Penjabaran lebih lanjut dari UUMK tertuang dalam peraturan mahkamah konstitusi (PM K). Dalam kaitannya dengan hukum acara pengujian undang undang, M K telah mengeluarkan PM K nomor 6 PM K tahun 2005. Secara spesifik, ketentuan tentang pendapat berbeda diatur dalam pasal 32 ayat (6). Bunyi lengkap dari ketentuan dalam pasal tersebut adalah "Pendapat $\mathrm{H}$ akim Konstitusi yang berbeda terhadap putusan dimuat dalam putusan, kecuali hakim yang bersangkutan tidak menghendaki". Dengan pengaturan yang demikian, bisa ditafsirkan bahwa bisa saja hakim memiliki pendapat yang berbeda dalam suatu rapat permusyawaratan hakim (RPH) namun pendapatnya tersebut tidak tertuang dalam putusan.

M eskipun UUMK tidak membedakan antara putusan dissenting dengan concurring, namun berbeda halnya dalam hal pengejawantahan dalam putusan MK. Putusan MK membedakan kedua jenis putusan tersebut dengan menggunakan frase "alasan berbeda" untuk menyebut concurring opinion dan frase "pendapat berbeda" untuk menyebut dissenting opinion. ${ }^{59} \mathrm{Dari}$ sisi penamaan, istilah tersebut memiliki

\footnotetext{
${ }^{57} \mathrm{Ibid}$. seb agai contoh, bisa dilihat pada putusan M K nomor 93/PUU-X/2012 tentang pengujian UU nomor 21 tahun 2008 tentang Perbankan Syari'ah yang memuat dua anggota majelis hakim yang mengajukan putusan concurring dan satu anggota majelis hakim yang mengajukan putusan dissenting.

${ }^{58} \mathrm{lbid}$.

${ }^{59}$ Lihat putusan MK nomor 016/PUU-VI/2008, 021-022/PUU-V/2007, 93/PUU-X/2012, 140/PUUVII/2009, 138/PUU-VII/2009, 120/PUU-VII/2009, 27/PUU-VII/2009. Disini Jimly dalam bukunya hukum acara pengujian undang-undang tidak membahasnya, dan mengatakan tak ada padanan kata untuk menyebut dissenting maupun concurring opinion.
} 
kelemahan karena keduanya tidak memuat karakteristik yang menjadi pembeda di antara keduanya.

Pengaturan pendapat yang berbeda dalam peraturan perundangundangan ini telah membuka peluang bagi adanya deliberasi di antara sesama hakim M K pada saat RPH . Komposisi beragam dari para personil hakimnya menjadikan ruang interpretasi terbuka lebar, termasuk untuk menggunakan reasoning yang berbeda. Kondisi ini menjadikan adanya kebutuhan terhadap hakim yang kompeten yang dapat menggunakan segala daya pikirnya untuk menghadirkan segala argumen dalam alasan memutusnya (ratio decidendi). D engan demikian, putusan tersebut akan menghadirkan argumentasi dari liyan (others) meskipun secara hukum tidak mengikat. Cara baca yang dekonstruktif bisa saja digunakan terhadap peraturan yang diujikan maupun terhadap norma yang menjadi batu ujinya. Betapapun, pemaknaan akan norma tersebut perlu untuk terus didiskusikan, tidak hanya oleh para hakim melainkan pula para pengacara serta pihak terkait. D engan seperti itu, maka semakin banyak perspektif yang muncul sehingga meminimalisir dominasi tafsir tertentu akan suatu teks.

\section{Simpulan}

Dari uraian di atas, bisa disimpulkan bahwa pemikiran Derrida tentang dekonstruksi sangat dipengaruhi oleh latar belakang kehidupannya. D ekonstruksi adalah strategi untuk mengurai teks sehingga memiliki kedekatan makna dengan istilah analisa. Tujuan dari metode dekonstruksi adalah untuk mengetahui dan membongkar selubung hirarkis yang ada pada teks sehingga tidak memberi kesempatan bagi adanya tafsiran tunggal atas teks. M etode ini dipakai sebagai respon Derrida atas logika modernisme yang banyak diwarnai dengan logosentrisme. M eskipun demikian, tak banyak tulisan D errida mengenai hukum dan keadilan yang ditemukan. $\mathrm{H}$ ukum dan keadilan bagi $\mathrm{D}$ errida tidaklah identik, karena itu untuk menggapai keadilan tawaran Derrida adalah melalui dekonstruksi.

Penegakan hukum dapat dilakukan melalui pengadilan oleh M K dalam bentuk pengujian terhadap undang-undang. Pengaturan tentang hukum acara pengujian ditentukan oleh peraturan perundang-undangan termasuk didalamnya adalah mengenai model putusan yang memuat pendapat yang berbeda. UUD NRI 1945 secara eksplisit tidaklah mengatur secara mendetail perihal pendapat yang berbeda ini, melainkan 
mengamanatkannya untuk diatur lebih lanjut dengan undang-undang. Sebagai tindak lanjut dari amanat tersebut, masalah dissenting opinion diatur melalui peraturan perundang-undangan. Peraturan perundangan yang mengatur tentang masalah dissenting opinion ini terdiri dari U ndang-U ndang N omor 24 Tahun 2003 dengan peraturan mahkamah konstitusi nomor 6 PM K tahun 2005 tentang hukum acara pengujian Undang Undang. Kedua peraturan perundang undangan tersebut memberi legitimasi bagi anggota majelis hakim untuk mengemukakan pendapatnya yang berbeda, meskipun pendapatnya tersebut berbeda dengan mayoritas hakim yang lain. Selain itu, dalam pengadilan semua pihak dapat didengar pendapatnya karena terdapat azas audi et alteram partem. D engan demikian, pengadilan dapat menghadirkan suara Liyan meski mayoritas tak sepaham.

\section{D aftar Rujukan}

Adam, Haidar. Putusan "Ultra Petita" Mahkamah Konstitusi dalam Perkara Pengujian Undang-undang. Skripsi: 2008.

Al-Fayyadh, M uhammad. Derrida. Cetakan keII, Yogyakarta: LKIS, 2012.

Aminah, Siti. dan Uli Parulian Sihombing, M emahami Pendapat Berbeda (D issenting 0 pinion) Putusan Uji M ateriil UU Penodaan Agama. J akarta: The Indonesian Legal Resource Center, 2011.

Asshiddiqie, Jimly. H ukum Acara Pengujian U ndang-U ndang. Jakarta: Sinar G rafika, 2012.

Asshiddiqie, Jimly. M enuju N egara Hukum yang D emokratis. Sekjend M KRI, 2008.

Ayu, Zendy Wulan. \& Haidar Adam. "Putusan Dissenting O pinion Mahkamah Konstitusi Dalam Perkara Pengujian UndangUndang". Yuridika: Volume 29 No 2, M ei-Agustus 2014.

D errida, Jacques. Force de loi: Le "fondement mystique de l'autorité", 11 CARDOZO LAW REVIEW 919-1045, (1990).

$\mathrm{H}$ ardiman, F. Budi. M elampaui Positivisme dan Modernitas. Jakarta: Kanisius, 2003.

Law, D avid S. and Versteeg, M ila, The Evolution and Ideology of G lobal Constitutionalism (June 13, 2011). California Law Review, Vol. 99, 2011; APSA 2010 Annual M eeting Paper; 5th Annual Conference on Empirical Legal Studies Paper; Washington U niversity in St. 
Louis Legal Studies Research Paper N o. 10-10-01. Available at SSR N : https://ssrn.com/abstract=1643628.

M ahdi, Imam. H ukum T ata N egara Indonesia. Yogyakarta: T eras, 2011. M ikics, D avid. Who Was Jacques D errida?: An Intellectual Biography. Yale U niversity Press, 2009.

M ulyadi, Lilik. Putusan H akim dalam H ukum Acara Perdata Indonesia. Bandung: PT Citra Aditya Bakti, 2009.

Putusan MK nomor 016/PUU-VI/2008, 021-022/PUU-V/2007, 93/PUU-X/2012， 140/PUU-VII/2009， 138/PUU-VII/2009, 120/PUU-VII/2009, 27/PUU-VII/2009.

Putra, Indra Sukma. Yulianti, Sri Wahyuningsih. Wicaksono, Bintoro Adi. "Analisis Putusan Dissenting O pinion berdasarkan Kitab Undang-Undang H ukumacara Pidana (KUHAP) Pada Perkara Penipuan (Studi Putusan Mahkamah Agung Nomor: 2253 K/Pid/2012), V erstek, Vol 3, No 3, 2015.

Setara Institute. Kinerja M ahkamah Konstitusi RI 2016-2017. Agustus 2017.

Sunarmi. "Dissenting O pinion sebagai Wujud Transparansi dalam Putusan Peradilan". Jurnal Equality. Vol. 12 N o. 2 Agustus 2007. Susanto, Anthon F. D ekonstruksi H ukum. Yogyakarta: Genta Publishing, 2010.

Syahrizal, Ahmad. Peradilan Konstitusi. Jakarta: Pradnya Paramitha, 2006.

Tim Penyusun Hukum Acara Mahkamah Konstitusi. Hukum Acara $M$ ahkamah Konstitusi, Sekretariat Jenderal M ahkamah Konstitusi. Tutik, Titik Triwulan. Pokok-Pokok Hukum Tata Negara Indonesia Pasca Amendemen U U D 1945. Jakarta: C erdas Pustaka, 2008.

"Kedudukan dan Kewenangan", http://www.mahkamahkonstitusi.go.id/index. php?page=web.Profil $M K \& i d=3$. 